\title{
RETHINKING BOTANIC \\ GARDENS: THE HUMAN \\ DIMENSION OF NATURE \\ IN SELECTED POEMS BY \\ MUHAMMAD HAJI SALLEH
}

\section{(Tanggapan Baharu Taman Botani: Dimensi Manusia oleh Alam dalam Puisi Pilihan Muhammad Haji Salleh)}

Sohaimi Abdul Aziz

soaazz@usm.my

School of Humanities,

Universiti Sains Malaysia,

11800 Penang, Malaysia.

Tel.:+604-6533858

\begin{abstract}
Botanic gardens have not changed much from the day they were established until today. Generally, a botanic garden is devoted to the collection, cultivation and display of a wide range of plants. In principle, its role is to maintain a documented collection of living plants for the purpose of scientific research, conservation, display and education. However, one of the major functions of botanic gardens is being ignored, that is, to instil and generate the sense of oneness between man and nature. Basically, man is inclined to destroy nature rather than preserve it for commercial reasons. Efforts to curb this problem have not been successful. Educational programmes conducted by botanic gardens to educate visitors with scientific information regarding nature have not been adequate. They have neglected the human dimension of nature which is so important in developing a sense of oneness between man and nature. Where and how to derive the human dimension from? This paper will explore the human dimension of plants as discovered in poetry written specifically about the human dimension to reveal the closeness between man and nature. Muhammad Haji Salleh, a well-known Malaysian poet, has written poems about plants that are common in tropical botanic gardens. Textual analysis
\end{abstract}


has been used to study the poems and has uncovered the human dimension in them. This discovery gives insight into a new model of botanic gardens as the manifestations of botany (science of plants) and poetry, thus providing the human dimension absent in previous models. According to this new model, then, botanic gardens have a new role to play in providing the educational programmes for the public.

Keywords: poem, human dimension, botanic garden, nature

\begin{abstract}
Abstrak
Sejak dahulu hingga ke hari ini, taman botani tidak banyak berubah dari segi fungsinya. Umumnya, taman botani memberi tumpuan pada koleksi, kultivasi dan pameran pelbagai jenis tumbuhan. Pada prinsipnya, taman botani berperanan memelihara koleksi tumbuhan hidup bagi tujuan penyelidikan saintifik, konservasi, pameran dan pendidikan. Walau bagaimanapun, salah satu fungsi taman botani telah diabaikan, iaitu menanam dan memberi kesedaran tentang kesatuan antara manusia dan alam. Atas alasan komersial, manusia cenderung untuk memusnahkan alam daripada memeliharanya. Usaha mengawal masalah ini masih belum berjaya. Program pendidikan yang berasaskan informasi saintifik yang dilaksanakan oleh taman botani untuk mendidik para pengunjungnya didapati tidak mencukupi. Dimensi manusia yang ada pada alam yang menjadi satu aspek penting kepada penyatuan manusia dengan alam telah diabaikan. Di mana dan bagaimana untuk mendapatkan dimensi manusia itu? Makalah ini meneroka dimensi manusia yang ada pada tumbuhan khususnya pokok melalui puisi-puisi yang dicipta oleh Muhammad Haji Salleh, seorang penyair terkenal di Malaysia yang telah menghasilkan puisi yang berkaitan dengan pokok-pokok yang terdapat di taman botani tropika. Analisis teks telah digunakan untuk mengkaji puisi-puisi tersebut. Kajian dapat membuktikan bahawa wujud dimensi manusia dalam puisi-puisinya. Dapatan ini telah memberikan satu wawasan baharu tentang satu model taman botani yang menjalinkan antara botani (science of botany) dengan puisi. Dengan demikian, model baru ini memberikan dimensi manusia kepada taman botani yang tiada dalam model-model taman botani yang ada sekarang. Dengan model yang baru ini, taman botani mempunyai peranan baharu dalam memberikan pendidikan kepada masyarakat umum.
\end{abstract}

Kata kunci: puisi, dimensi manusia, taman botani, alam 


\section{INTRODUCTION}

Nature has an important meaning to the traditional communities in East and Southeast Asia, such as Japan, Korea and Malaysia. Nature is a manifestation of the spirit, which is close to them. Strong animistic beliefs underlying their thinking are reflected in their everyday life. Without nature, there is no life. Nature must be respected and not exploited (Abdul Rahman, 1998). The close relationship between man and nature is revealed in the Malay traditional poetry known as pantun. The pantun consists of two parts, the first two lines are known as the foreshadower and the second two lines are the meaning. The foreshadower in the pantun form includes mention of elements of nature such as birds, plants, flowers, fruits and insects. The following is a well-known four-line pantun:

\section{Dari mana punai melayang? \\ Dari sawah turun ke kali; \\ Dari mana datang sayang? \\ Dari mata turun ke hati. \\ (Whence flies the dove? \\ From the fields to the stream; \\ Whence comes love? \\ From the eyes into the heart.)}

(Muhammad, 1991:39)

The elements of nature in the first two lines (the foreshadower) are the dove, the paddy field and the stream, and the next two lines (the meaning) talk about falling in love. The foreshadower and the meaning form a meaningful pantun and this unity reflects the unity between nature and man. Nevertheless, the influence of foreign elements, especially from the West, has had an impact on the emergence of new forms of poetry which are no longer focused on a foreshadower, such as the open form (also called "free verse") poetry. As a result, the emergence of the open form poetry, known as sajak, has affected the popularity of the traditional pantun. This development reflects the socio-cultural changes that have occurred in Malay society, which has been influenced by imperialism and capitalism. When capitalism is strong, nature is subjugated by man and, finally, the exploitation of nature becomes rampant under the guise of development. In due course, some of the Malay poets began to separate themselves from the influence of nature. Muhammad, 
who is one of the most celebrated poets in Malaysia, continues to celebrate the importance of nature in his poems.

In Japanese tradition, the philosophy of Zen Buddhism also believes in the concept of the oneness of man with nature. This concept is reflected in the poetic form known as haiku. A haiku written by the well-known Zen poet Matsuo Basho goes as follows:

\section{Furuikeya \\ kawazutobikomu \\ mizu no oto \\ (The old pond; \\ A frog jumps in -, \\ The sound of water.)}

(Aitken, 1978: 25)

"The Old Pond" is a classic haiku which about the poet experiencing nature. The poet writes about what comes to his mind as he looks at a frog in its habitat. Surrounded by nature, Basho experiences a state of mind of total absorption. The relationship between man and nature, between finite and the infinite is a form of spiritual experience. The concept of oneness of man with nature is embedded between the poet's lines and words. The concept of oneness of man and nature in the new model of botanical garden is different from the concept of oneness in haiku; it is cognitive and emotional in nature.

\section{BOTANIC GARDENS}

Botanical gardens are establishments which are designated for the documenting of collections of living plants for the purposes of scientific research, conservation, display and education. Displaying plants for educational and scientific purposes has become the major function of botanic gardens. William Stern, as quoted by Schultes, says:

... a botanic garden may be defined as a garden organized primarily for botanical research or instruction or both; its recreational value, often high, stands subordinate to this. Being educational and scientific in function and not dominated by aesthetic and utilitarian considerations, a botanic garden has a duty to maintain in cultivation a diversity of plants for their interest, 
some indeed with little beauty or no evident use to command them, so that they may be kept available for botanical study.

(Schultes, 1983:4)

The Penang Botanic Gardens fulfil a similar purpose:

Today, the Gardens' main objectives include conservation programmes, provision of a clean, safe and conducive public recreation environment, education and raising of public awareness on the appreciation of nature and gardening. In the research area, the Gardens also collaborate with others in the development and implementation of botanical and ecological research programs both nationally and internationally.

(A Guide to the Penang Botanic Gardens, 2000:6).

Botanic gardens are not only for scientific and educational purposes but also for commercial ones. For example, the Kew Gardens in Britain, being one of the renowned botanic gardens in the world, played their part in economic botany:

Kew Gardens played a major part in the development of several highly profitable and strategically important plant-based industries in the tropical colonies. These new plantation crops complemented Britain's home industries to form a comprehensive system of energy extraction and commodity exchange which for a time, in the nineteenth and early twentieth centuries, made Britain the world's superpower.

(Brockway, 1979:6)

Economic botany still exists today although not on as grand a scale as in the Kew Gardens in those days. The models of botanic gardens such as the classic European model (which focused more on taxonomic study), the colonial tropical model (focusing on botany for trade and commercial purposes), the civic and municipal model (focusing on horticultural aspects) and the agricultural model (for cultivation of and research on agricultural or horticultural plant species) are basically lacking when it comes to promoting the idea of the oneness of man and nature. According to Heywood (1987:17), in recent years, botanic gardens are beginning to look to genetic conservation as one of their major goals. Many scientific facilities such as herbaria, libraries and laboratories have been built, while taxonomic and floristic studies have 
been getting greater attention (Heywood, 1987:16). In other words, botanic gardens serve scientific and economic purposes. Educational purposes are also crucial but there is a great lack in this area. The educational role of botanic gardens has been growing far more slowly than their scientific role. This paper intends to introduce a new model for botanic gardens model which emphasises the oneness of man and nature, as derived from poetry written specifically about nature. Through poetry, man and nature may come together and build a relationship of oneness.

Displaying scientific information regarding plants is only a part of what should be offered to the public. They should not only be given scientific knowledge about the plants available at a particular botanic garden but also the opportunity to engage with the plants cognitively and emotionally. Plants should not be regarded merely as scientific objects because plants are a part of nature and thus a reflection of human life. There is a great connection between man and nature. Traditionally, the connection between man and nature is a major part of their cultural and religious activities, as mentioned earlier. However, modernity has interrupted this connection, resulting in man destroying nature for the sake of economic and societal purposes.

In other words, botanic gardens exist in many forms and with a multiplicity of functions. However, their crucial function, which has to do with the oneness of man and nature, has been forgotten and deprived.

As a result, nature is continuously being destroyed. Consequently, environmental issues have become major issues affecting mankind. The existing approach by botanic gardens in educating visitors is insufficient to overcome the severe environmental problems faced by the world. Thus, rethinking the concept of botanic gardens is necessary and this paper attempts to provide realistic and practical ideas to this end. Botanic gardens should inject a human dimension into their educational activities. Plants should be viewed and understood from a psychological perspective, extending their human dimension. This human dimension may be explored by people of great sensitivity and imagination, such as writers and poets. Their perception of nature is beyond that of ordinary man. Nature becomes the source of creativity for poets. Muhammad, a prominent Malaysian poet, is among them.

\section{POETRY AND THE HUMAN DIMENSION OF NATURE}

Muhammad writes poems about man and nature in an artistic manner with a human dimension of nature beautifully embedded in the lines and words. The human dimension is beautifully crafted and reflected in his poetry, which 
have been published in his recent anthology entitled An Emerald Hill by the Sea (2011). Muhammad has an intimate relationship with nature, as he mentions in the preface to the anthology:

As a poet I observe and drift along on yearly rhythms, am drenched or parched by seasons, stopped short by butterflies, kingfishers or monitor lizards; my days are ornamented by angsana, Morinda and saga, flame of the forest and also a hundred flowers that were planted or have grown were before I set foot here. In all of these I read qualities, characters, personalities, and meanings of rocks leaves, flowers, insects, and animals.

(Muhammad, 2011:xi).

For Muhammad, the elements of nature are very familiar to him and have become such a part of his life that he is able to feel their pulse and the rhythm of their every beat. For Muhammad, nature has a spirit and this spirit becomes a bridge that links him to nature. With this close and subtle relationship, Muhammad manages to write beautiful poems that reflect a human dimension. This human dimension is also his inner consciousness towards the elements of nature.

In his anthology titled An Emerald Hill by the Sea (2011), Muhammad has enriched his poems with elements of nature such as plants, insects, flowers, rocks and these elements are given a human dimension. Nature comes alive in the poetry of Muhammad, and this produces an effect on the reader by making the reader feel the vitality and the vibrance of nature. Eventually, this effect transforms into an aesthetic experience and with this experience, the reader will be more conscious of the need for loving nature, and will awaken to the importance of caring for and preserving it. With the suggestive power of the poems and the aesthetic experience experienced by the reader, there will grow a deep ecological ethics which will manifest in the form of positive attitude and actions towards nature.

Through his poetry, Muhammad could contribute to sustainable development and environmental management. His poems could create an awareness of the importance of managing nature according to the needs of present and future generations. Muhammad's poetry could nurture and foster the human relationship with nature in readers. With such a relationship, man could develop a strong ecological ethics allowing him to control himself in dealing with nature because such ecological ethics will ensure that man cares for nature and treats it with the utmost love and acts responsibly. This 
attitude will ensure that nature will be conserved and preserved for future generations. Muhammad, in his poem entitled "The Flame of the Forest," says:

flame of the forest

reflects the sun

its blooms mark the drought with strokes

and brace the dome of the sky.

the trunk stretches

waking from the cold

leaves as fine as a baby's curls.

None is more beautiful

than sparklers.

That sprinkle colour on the canopy's curve

even the drought is discoloured

by a crimson future.

(Muhammad, 2011:4)

The flame of the forest is a tree which is scientifically known as Delonix regia. This tree is adapted to hot and dry weather and thus can be found in tropical and subtropical countries, including Malaysia. The flame of the forest produces a lot of flowers with bright and vivid colours such as red and yellow.

The flames of the forest tree which can be found on the campus of Universiti Sains Malaysia where Muhammad is one of the members of the academic staff inspired him to write this poem. In "The Flame of the Forest," Muhammad depicts the human dimension of nature by linking the red flowers of this tree with energy and life. The red flowers are like the sun which is bright and energetic.

The beauty and diversity of the nature should be appreciated by man. It can become his companion and teacher. Nature should be treated with due respect. Muhammad, in another poem entitled "shade of the angsana" writes about a student and a tree. The poem goes as follows:

a student

shelters in the green shadow

his life smells of wood sweetness of the kernel and so he sips the clean vapours of the canopy there he gathers the chill 
in his cupped hands

because he is kin

in a large clan

to which all belong.

there he tastes the water

that is purified by leaves

and returns

the essence of breath awaited

green by his sister.

the dome of cool fragrances

shelter is a pleasant shared.

from here

the yellow of the angsana

this is lodged his hair.

(Muhamm ad, 2011:12)

The angsana tree (scientific name - Pterocarpusindicus) can grow up to 40 meters tall and its trunk can be up to 2 meters in diameter. In this poem, it becomes the shelter to protect a student from the sweltering heat. The student can smell the scent of the angsana tree which protects him from the heat of the sun. Biological interaction occurs between man and nature because through breathing, the student exhales carbon dioxide which the tree turns into fresh oxygen through the process of photosynthesis that takes place in its leaves. . The relationship between the student and the tree as reflected in Muhammad's poem is a manifestation of the relationship between man and nature:

a student shelters in the green shadow,

his life smells of wood sweetness of the kernel, and so he sips the clean vapours of the canopy.

Nature, represented by the angsana tree, has a biological relationship with man. The relationship is a mutual one in which both parties, man and nature, are expected to give and take among one other. The angsana tree is alive and contributes to the well-being of man. Similarly man has a role to play in safeguarding this relationship. He should not destroy nature but love and protect it. 
The angsana tree and the student interact in a biological and pure manner. Muhammad further says: there he tastes the water, that is purified by leaves, and returns, the essence of breath awaited, green by his sister.

The relationship between nature and man should be sincere and loving. As a result, any exploitation towards nature is not condoned, as implied in this poem. Muhammad's poem convinces readers that nature needs respect and caring. In other words, there is a strong suggestion for the reader to embrace nature.

The poems in An Emerald Hill by the Sea are divided according to sections, with each section linked to a specific month, from January to December. Each month is linked to the weather. For example, January is the dry season, while February is rainy. Actually, the poems for each month reflect a specific season, representative of the weather in Malaysia. In Malaysia, the flowers of the flame of the forest bloom in the dry season. The hot dry season is neutralized by the arrival of the bright flowers of the tree. The ability of the flames of the forest to adapt to the dry season is associated with the life of man. Muhammad believes that man should also adapt himself to the surrounding and stay energetic through good and bad times. In other words, man has a lot to learn from nature.

After January comes the month of February. February is the start of the rainy season, and it brings new life to nature. This is the background to the poems entitled "Mangkudu at February End" and "February Mangkudu". The mangkudu', or-Morinda citrifolia, as it is scientifically known, is a tree of moderate size, with big or small leaves. This tree captures Muhammad's imagination and in these poems Muhammad describes the nature of the mangkudu. According to Muhammad:

Contemplative in character

bent on observing

its own soul

its small leaves and coy

density but hides a personality.

(Muhammad, 2011:23)

Clearly, this tree, for Muhammad, reflects a humble personality and character. More about why this tree captures the poet's imagination can be detected from one of the verses of the other poem, "February Mangkudu": 
your name is not beautiful

but in the hands of the physician, you become the antidote for sorrows, easing and assisting.

(Muhammad, 2011:20)

According to Muhammad, the name of this tree is not beautiful but to a physician, this tree is special. According to Muhammad, those who have knowledge about this tree use it for medicine. In Malay society, the mangkudu is used in traditional medicine. The leaves, fruits, barks and roots of the mangkudu can be used to treat bleeding, asthma, cough and malaria. The shoots are known as ulam are cooked and eaten. The tree's ugly fruits are used in the treatment of asthma and cough. The water of the boiled bark is drunk to treat malaria and also becomes an astringent to stop bleeding by shrinking the blood vessels. Just like the humble mangkudu that in reality has many medicinal uses, man should be humble and ever willing to contribute to the well-being of nature or planet Earth. Man should regard nature as his companion and teacher. Nature, such as trees and plants, has the right to be respected, and man should manage them intelligently by allowing them to grow.

\section{CONCLUSION}

The human dimension of these selected trees is an example of how the new model of botanic garden should be. The number of trees that have been given a human dimension by the poet is considered small compared to the numbers of plants in a particular botanic garden; nevertheless the significance of the nature of these plants and their relationship with man as seen in the poems selected becomes the fundamental principle underlying the new model of future botanic gardens. The awareness of caring and conserving nature should be cultivated meticulously in order to have a better understanding of a oneness with nature. The human elements that colour the elements of nature in the poems studied have a strong suggestive power that makes readers feel a oneness with nature in which they are to understand their own existence. Muhammad has contributed to the better understanding of how man should act by creating an awareness about the biological interaction between man and nature and this approach towards nature should be integrated into the new concept of botanic gardens. New technology can be employed in the new-model botanic gardens, such as kiosks and mobile applications. 


\section{REFERENCES}

A Guide to to the Penang Botanic Gardens, 2000. Penang: Friends of Penang Botanic Gardens Society.

Abdul Rahman Ismail,1998. Falsafah Alam Semesta di Nusantara. Tradisi dan Reaksi dalam Sejarah Kosmologi Melayu (The Philosophy of Nature in the Malay Archipelago: Tradition and Reaction in the History of the Malay Cosmology). Sungai Petani: Yusran Publishing House.

Aitken, Robert, 1978. A Zen Wave. Basho's Haiku and Zen. New York and Tokyo: John Weatherhill, Inc.,

Brockway, Lucile H., 1979. Science and Colonial Expansion. The Role of the British Botanic Gardens. New York: Academic Press.

Heywood, V. H., 1987. "The Changing role of Botanic Gardens" in D. Bramwell, O. Hamann, V. Heywood, H. Synge (ed). Botanic Gardens and the World Conservation Strategy. London: Published for IUCN By Academic Press. pp.3-18. Muhammad Haji Salleh,1991. Yang Empunya Cerita. The Mind of the Malay Author. Kuala Lumpur: Dewan Bahasa dan Pustaka.

Muhammad Haji Salleh, 2011. An Emerald Hill by the Sea. Poems of Nature USM (English Translation). L. Sinha \& Md. Salleh Yaapar (transl). Penang: Universiti Sains Malaysia Publisher.

Schultes, Richard E., "Botanical Museums and Gardens and Their Role in Conservation of Germ Plasm" in Porim Occasional Paper. No. 7, pp. 1-19, April 1983. 